DOI: $10.14720 /$ aas.2016.107.2.13

Agrovoc descriptors: Weed control, cultural weed control, zea mays, maize, Abutilon theophrasti, plant competition, weed competition, weeds, noxious plants, cover plants, Phaseolus vulgaris, Glycine max, Trifolium alexandrium

Agris category code: H01, H60, F08

\title{
Effect of cover crops on maize-velvet leaf competition: leaf area density and light interception
}

\author{
Zahra SHAKIBAFAR $^{1}$, Faezeh ZAEFARIAN ${ }^{2 *}$, Mohammad REZVANI ${ }^{1}$, Hamid SALEHIAN ${ }^{1}$
}

Received April 25, 2016; accepted September 12, 2016.

Delo je prispelo 25. aprila 2016, sprejeto 12. septembra 2016.

\begin{abstract}
Cover crops influence on canopy structure and light interception of maize (Zea mays L.) and velvetleaf (Abutilon theophrasti Medik), was studied in a field experiment. Treatments included planting of bean (Phaseolus vulgaris L.), soybean (Glycine $\max$ (L.) Merr.) and berseem clover (Trifolium alexandrium L.) as cover crops at the same date and 21 days after maize. Sole cropping of maize under weed- free and weedy conditions were also included in this experiment All tested cover crops significantly reduced leaf area density and height of velvetleaf up to $50 \%$, while maize leaf area density increased in the presence of cover crops. Among cover crops, bean and soybean were the most effective in reducing velvetleaf leaf area density and height. Bean and soybean also strongly reduced absorbed light by velvetleaf by up to $80 \%$ compared to clover. Maize grain yields were significantly influenced by cover crops planting in the inter row space. Compared to weeds free plots, only treatment with soybean as a cover crop resulted in similar maize grain yields, while maize intercropping with bean and clover significantly reduced maize yields. Delayed planting of cover crops, 21 day after maize, increased maize grain yield compared to cover crops and maize planting at the same time.
\end{abstract}

Key words: canopy structure, leaf area density, light interception, leaf area index, maize, velvetleaf, weed competition

\section{IZVLEČEK}

\author{
UČINEK PODSEVKOV NA TEKMOVALNOST MED \\ KORUZO IN BRŽUNASTIM OSLEZOM: GOSTOTA \\ LISTNE POVRŠINE IN PRESTREZANJE SVETLOBE
}

V poljskem poskusu je bil preučevan vpliv podsevkov na zgradbo sestoja in prestrezanje svetlobe koruze (Zea mays L.) in bržunastega osleza (Abutilon theophrasti Medik). Obravnavanja so obsegala setev nizkega fižola (Phaseolus vulgaris L.), soje (Glycine $\max$ (L.) Merr.) in aleksandrijske detelje (Trifolium alexandrium L.) kot podsevkov, posejane istega dne kot koruza ali 21 dni po njeni setvi. V poskus sta bili vključeni tudi 2 kontroli (čista setev koruze z zatiranjem in brez zatiranja plevelov). Vsi preizkušeni podsevki so značilno zmanjšali gostoto listne površine in višino bržunastega osleza do $50 \%$, medtem ko se je gostota listne površine koruze $\mathrm{v}$ prisotnosti vseh treh podsevkov povečala. Med podsevki sta bila fižol in soja najbolj učinkovita $\mathrm{v}$ zmanjševanju gostote listne površine in višine bržunastega osleza. Fižol in soja sta $\mathrm{v}$ primerjavi $\mathrm{z}$ deteljo najmočneje zmanjšala absorbirano svetlobo bržunastega osleza, do $80 \%$. Podsevki v vrste med koruzo so značilno vplivali na pridelek njenega zrnja. V primerjavi s kontrolo brez plevela je samo obravnavanje s sojo kot podsevkom dalo podobne pridelke, podsevka fižola in detelje sta značilno zmanjšali pridelek zrnja koruze. Odložena setev podsevkov, 21 dni po setvi koruze, je povečala pridelek zrnja koruze $\mathrm{v}$ primerjavi $\mathrm{z}$ obravnavanji, ko so bili koruza in podsevki posejani istočasno.

Ključne besede: zgradba sestoja, gostota listne površine, prestrezanje svetlobe, indeks listne površine, koruza, bržunasti oslez, tekmovalnost plevelov

\footnotetext{
1 Department of Agronomy and Plant Breeding, Qaemshahr Branch, Islamic Azad University, Qaemshahr, Iran

2 Department of Agronomy, Faculty of Crop Sciences, Sari Agricultural Sciences and Natural Resources University, Sari, Iran; ${ }^{*}$ Corresponding author email: fa_zaefarian@ya
} 


\section{INTRODUCTION}

Herbicide application, as one of the common weed control method in modern agricultural ecosystems, has an important role in environmental contamination (Campiglia et al., 2010). One of the environmentally friendly method in weed control is using cover crops between the rows of the main crop. The weed suppression through cover crops has been reported by many researchers (Hiltbrunner et al., 2007; Hollander et al., 2007; Campiglia et al., 2009; Ngouajio et al., 2003). In fact, a living cover crop can decrease weed growth, improve soil structure and can also improve fertility of soil through addition of organic fertilizer (Shili-Touzi et al., 2010; Abdin et al., 2000). Also, it has been shown that cover crops can reduce the frequency of weeds and increase main crops yield (Udenesi et al., 1999). Plants from Fabaceae family have been extensively used as cover crops for soil fertility and smothering weeds (Hiltbrunner et al., 2007), although a variable potential of weed control has been reported for different leguminous crops (Olorunmaiye, 2010).

Light is one of the crucial factors affecting on competition in mixed canopy (Vazin et al., 2010). The total photosynthetically active radiation (PAR) intercepted and distribution of light in plant canopy are important for evaluating the potential carbon uptake by crop (Sassenrath-Cole, 1995). Light interception and attenuation are determined by canopy structure (Maddonni et al., 2001). The leaf area index, plant height, vertical leaf area distribution and leaf angle distribution are factors that play key role in evaluating of competition for light in mixed canopies (Lindquist and Mortensen, 1999). Moreover, vertical profile of leaf area density affects the light interception and consumption, dry matter accumulation and grain yield (Ciganda et al., 2008). In a mixed canopy, vertical distribution of leaf and solar radiation can be used to study of light competition among plants (Uchino et al., 2012). Steinmaus et al. (2008) also noted that cover crops suppressed weed through reduction of light interception by weed. Utilization of broadleaf legumes as cover crops between maize rows could provide nitrogen for main plant and reduce available space for weed development. However, it is necessary to evaluate different cover crops and choose the desirable ones.

Velvetleaf is one of the most troublesome weed in maize fields in the north of Iran. The objective of this experiment was to evaluate the cover crops and their roles in reduction of velvetleaf pressure in maize through the reduction in canopy properties and light interception.

\section{MATERIALS AND METHODS}

The experiment was conducted in a research-field at the Sari Agricultural Sciences and Natural Resources University, Iran $\left(39^{\circ} 36^{\prime} \mathrm{N}, 53^{\circ} 04^{\prime} \mathrm{E}\right.$, $12 \mathrm{~m}$ above sea level) in 2011. The soil type was silty clay $\left(\mathrm{pH} 7.52, \mathrm{~N} 23 \%, \mathrm{P} 14 \mathrm{mg} \mathrm{g} \mathrm{g}^{-1}, \mathrm{~K}\right.$ $\left.278.05 \mathrm{mg} \mathrm{kg}^{-1}\right)$. Average annual precipitation and temperature were $892.4 \mathrm{~mm}$, and $17.1{ }^{\circ} \mathrm{C}$, respectively. In order to meet nutrient requirements of maize as the main crop, a nitrogen rate of $200 \mathrm{~kg} \mathrm{ha}^{-1}$ as urea fertilizer and $250 \mathrm{~kg} \mathrm{ha}^{-1}$ ammonium phosphate fertilizer were added before planting. Also, a nitrogen rate of $200 \mathrm{~kg} \mathrm{ha}^{-1}$ as urea fertilizer was added when maize was in 6-8 leaves stages. Irrigation was done by a drip irrigation system during the experiment.
The treatments were arranged in a randomized complete block design with three replicates. Treatments included the planting of bean (Phaseolus vulgaris 'Sunrise'), soybean (Glycine max 'Sari'), and berseem clover (Trifolium alexandrium 'Carmel') as cover crops at the same date (first planting date) and 21 days (second planting date) after maize sowing (Zea mays 'SC704'). In addition, sole cropping of maize under weed control and weed infestation were also included. The plants were sown in plots with an area of $5 \times 3.75 \mathrm{~m}^{2}$, included 5 rows of maize (with $75 \times 20 \mathrm{~cm}$ spacing) and 6 rows of cover crops (with $75 \times 5 \mathrm{~cm}$ spacing). The dominant weed (up to $65 \%$ of the total weed population densities) in this study was velvetleaf as the highest density was recorded (on average, 150 plant $\mathrm{m}^{-2}$ ) and the other 
weeds were removed by hand during the growing season.

For evaluation of leaf area density and absorbed light in canopy, leaf area index of plants was measured by a LAI meter (Li-COR, Model LI$3100 \mathrm{~A}$, USA), at 77 days after sowing (maize silking stage, soybean and bean were at early flowering stage but clover was at complete flowering stage and velvetleaf was at flowering stage). In addition, height of plants was measured at the same time as measuring leaf area.

Leaf area density (LAD) and light interception were recorded and analyzed with the INTERCOM model (Kropff et al., 1993). This model was chosen as it was possible to calculate profile and light interception in mixed stands of species (Kropff et al., 1993). Solar radiation per day was obtained from Mazandaran meteorological station. The daily PAR was evaluated to be half of the global radiation. The light interception by plants in mixed and sole treatments was calculated at 77 day after maize planting using equations 1 to 3 (Kropff et al., 1993):

Table 1: Light extinction coefficients $(k)$ for plants
Equation 1

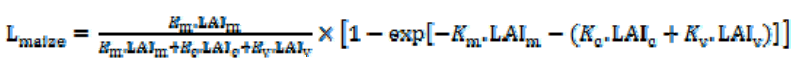

Equation 2

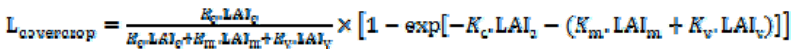

Equation 3

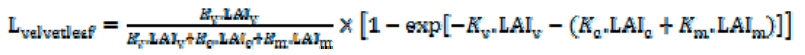

where $\mathrm{L}_{\text {maize, }} \mathrm{L}_{\text {covercrop }}$ and $\mathrm{L}_{\text {velvetleaf }}$ are data for light captured by maize, cover crops and velvetleaf, respectively. $k_{\mathrm{m}}, \quad k_{\mathrm{c}}, \quad k_{\mathrm{v}}$ are light extinction coefficients of maize, cover crops and velvetleaf, respectively. $\mathrm{LAI}_{\mathrm{m}}, \mathrm{LAI}_{\mathrm{c}}, \mathrm{LAI}_{\mathrm{v}}$ are leaf area indexes of maize, cover crops and velvetleaf, respectively.

The light extinction coefficient $(k)$ for each plant in this trial was an average of what has been reported previously by other researchers (Table 1 ).

\begin{tabular}{llll}
\hline Plant & $\boldsymbol{K}$ & References & $\boldsymbol{k}$ Average \\
\hline \multirow{3}{*}{ Maize } & 0.65 & Maddonni et al., 2001 & 0.59 \\
& 0.67 & Lindquist et al., 2005 & \\
\hline \multirow{3}{*}{ Soybean } & 0.6 & Flenetet al., 1996 & 0.69 \\
& 0.47 & Liu et al., 2012 & \\
\hline \multirow{2}{*}{ Bean } & 0.62 & Flenet et al., 1996 & \multirow{2}{*}{0.66} \\
\hline Berseem clover & 0.81 & Wang et al., 2001 & 0.41 \\
\hline \multirow{2}{*}{ Velvetleaf } & 0.81 & Dermodyet al., 2008 & 0.68 \\
\hline
\end{tabular}

Vertical distribution of light in canopy was calculated according to the model described by Nasiri and Kropff (1997). The LAI, dry mass and height data were analyzed using an analysis of variance (ANOVA) using the SAS software (Ver. 9.2). Means were separated using a least significant difference (LSD) at the $5 \%$ level of probability. 


\section{RESULTS AND DISCUSSION}

\subsection{Dry matter, height and leaf area index}

The highest dry matter of maize was obtained from soybean cover crop when planted at the same date with the maize. There were no significant differences between treatments where soybean planted 21 days after maize sowing and sole cropping of maize under weed infestation in dry matter of maize (Table 2). Maize in treatments when soybean as the cover crop was planted at the same date of maize sowing, produced the highest dry matter compared to other cover crops. The lowest maize dry matter was recorded in treatments where clover was the cover crop (Table 2 ). The highest velvetleaf dry matter was observed in sole cropping of maize under weed infestation. The dry matter of velvetleaf was not significantly different among the other treatments (Table 2).
The highest value of maize LAI was observed in treatments where bean was planted 21 days after maize sowing (second planting date) (Table 2). Clover planted 21 days after maize sowing reduced the LAI of maize and the lowest maize LAI was recorded in this treatment (Table 2). Unayet al. (2005) also reported that the presence of cover crops increased the leaf area index of cotton. The LAI of bean and soybean was higher than the clover (Table 2). Hollander et al. (2007) showed that LAI of berseem clover was lower compared to other clover species used as a cover crop. There was no significant difference in LAI between both planting dates of bean and soybean, nevertheless the highest leaf area index of cover crops including soybean and clover was observed in the second sowing date (Table 2).

Table 2: Effect of experimental treatments on dry matter, LAI and height of maize, cover crops and velvetleaf

\begin{tabular}{|c|c|c|c|c|c|c|c|c|c|}
\hline \multirow[b]{2}{*}{ Treatments } & \multicolumn{3}{|c|}{ Dry matter $\left(\right.$ g plant $\left.^{-1}\right)$} & \multicolumn{3}{|c|}{ Leaf area index (LAI) } & \multicolumn{3}{|c|}{ Height $(\mathrm{cm})$} \\
\hline & Maize & $\begin{array}{l}\text { Cover } \\
\text { crops }\end{array}$ & Velvetleaf & Maize & $\begin{array}{l}\text { Cover } \\
\text { crops }\end{array}$ & Velvetleaf & Maize & $\begin{array}{l}\text { Cover } \\
\text { crops }\end{array}$ & Velvetleaf \\
\hline Bean (T1) & $179.58 \mathrm{abc}$ & $3.33 \mathrm{bc}$ & $0.77 b$ & $2.98 b c$ & $2.62 \mathrm{a}$ & $0.13 c$ & 197.5 & $73.02 b$ & $69.33 c$ \\
\hline Bean (T2) & $221.65 \mathrm{ab}$ & $2.88 \mathrm{bc}$ & $0.19 b$ & $3.71 \mathrm{a}$ & $3 \mathrm{a}$ & $0.11 \mathrm{c}$ & 202.4 & $61.72 b c$ & $32.67 d$ \\
\hline Soybean (T1) & $245.06 \mathrm{a}$ & $9.97 \mathrm{a}$ & $1.17 \mathrm{~b}$ & $3.3 \mathrm{ab}$ & $3.63 \mathrm{a}$ & $0.08 \mathrm{c}$ & 202.5 & $101.2 \mathrm{a}$ & $71.67 \mathrm{c}$ \\
\hline Soybean (T2) & $232.1 \mathrm{a}$ & $5.65 b$ & $0.17 b$ & $3.2 \mathrm{~b}$ & $4.18 \mathrm{a}$ & $0.17 \mathrm{c}$ & 211.6 & $94.82 \mathrm{a}$ & $31.33 \mathrm{~d}$ \\
\hline Clover (T1) & $127.85 \mathrm{c}$ & $0.78 \mathrm{c}$ & $2.08 \mathrm{~b}$ & $2.5 \mathrm{~cd}$ & $0.43 b$ & $1.07 \mathrm{~b}$ & 196.87 & $55.18 \mathrm{~cd}$ & $75 \mathrm{c}$ \\
\hline Clover (T2) & $120.89 c$ & $0.31 \mathrm{c}$ & $1.91 b$ & $2.43 \mathrm{~d}$ & $0.14 b$ & $4.84 \mathrm{a}$ & 196.9 & $41.83 \mathrm{~d}$ & $101.67 b$ \\
\hline Maize (W) & $209.87 \mathrm{ab}$ & - & $70.5 \mathrm{a}$ & $2.93 \mathrm{bc}$ & - & $5.53 \mathrm{a}$ & 195.2 & - & $230 \mathrm{a}$ \\
\hline Maize (WF) & $148.93 \mathrm{bc}$ & - & - & $3.04 \mathrm{~b}$ & - & - & 192.6 & - & - \\
\hline LSD (5\%) & 79.12 & 3.49 & 12.23 & 0.49 & 0.68 & 0.82 & 12.85 & 17.25 & 10.18 \\
\hline $\mathrm{SE}( \pm)$ & 17.16 & 1.45 & 9.92 & 0.1473 & 1.69 & 0.91 & 2.13 & 9.43 & 25.54 \\
\hline $\begin{array}{l}\text { Significance } \\
\text { level }\end{array}$ & $*$ & $* *$ & $* * *$ & $* *$ & $* *$ & $* * *$ & N.S. & $* * *$ & $* * *$ \\
\hline $\begin{array}{l}\text { Coefficient of } \\
\text { variation }(\%)\end{array}$ & 24.31 & 50.35 & 62.71 & 9.39 & 39.73 & 27.19 & 3.68 & 13.3 & 6.55 \\
\hline
\end{tabular}

T1: The first sowing date of cover crops (same date planting with maize), T2: The second sowing date of cover crops (21 days after planting of maize), W: Weedy, WF: Weed-free.

$*$, **, *** indicated significant at $P \leq 0.05, P \leq 0.01$ and $P \leq 0.001$, respectively. N.S., indicates no significant difference. Means in the same column bearing the same letter(s) are not significantly different from each other at the $5 \%$ level of probability.

The presence of bean and soybean reduced the LAI of velvetleaf compared to maize sole crop under weedy condition. The highest leaf area index of velvetleaf was recorded in maize sole crop under weedy condition and in the treatment where clover was planted 21 days after maize sowing. Furthermore, delayed planting of clover resulted in significantly lower clover plant height and LAI compared to the other cover crops (Table 2). Intercropping with bean and soybean decreased leaf area density of velvetleaf on average for 97.83 $\%$ and $97.74 \%$, respectively (Table 2 ). Hiltbrunner et al. (2007) stated that enhancement of cover crops development and dry matter, decreased the weed dry matter. Also, it was reported that planting legume cover crops resulted in reduction of weed 
establishment as live legume cover is the best known to smother weeds (Akobundu, 1982). The greatest plant height of maize was recorded in the second sowing date of soybean treatments, and the shortest plants of maize were observed in maize sole crop under weed-free condition (Table 2). Among cover crops, treatment with soybean had the greatest maize plant height. The absence of cover crops in maize increased the height of velvetleaf. The velvetleaf height was significantly reduced in treatments where soybean and bean were planted 21 days after maize planting (Table 2). Barker et al. (2006) reported that competition of maize strongly reduced velvetleaf $\mathrm{LAI}_{\max }$ and height, but velvetleaf only reduced maize height by up to $2 \%$.

\subsection{Leaf area density}

The assessment of leaf area density showed that bean and soybean at both planting dates decreased the LAD of weed more significantly than clover
(Figures 1a, 1b, 1d, 1e). In addition, the maximum leaf area density $\left(\mathrm{LAD}_{\max }\right)$ of velvetleaf was distributed at higher layer of canopy compared to $\mathrm{LAD}_{\max }$ of clover (both planting date) (Figures 1c, 1f). In contrast, $\mathrm{LAD}_{\max }$ of bean and soybean was observed to be positioned at upper canopy layer than that of velvetleaf $\mathrm{LAD}_{\text {max }}$ (Figures 1a, 1b, 1d, 1e). The low LAD of clover increased the LAD of weed, especially at the second sowing date (Figures 1c, 1f). However, leaf area density of weed in presence of clover was lower than sole planting of maize under weedy conditions (Figures $1 \mathrm{c}, 1 \mathrm{f}, 1 \mathrm{~h})$. In general, the $\mathrm{LAD}_{\max }$ of velvetleaf was lower than $\mathrm{LAD}_{\max }$ of bean and soybean (Figures 1a, 1b, 1 d, 1e), which indicated greater competitive ability of this two plants compare to velvetleaf. Our findings was in according to Vazin et al. (2010) results. Uchino et al. (2012) reported that LAI of weed decreased due to increasing of leaf area and growth of main crops and cover crops.

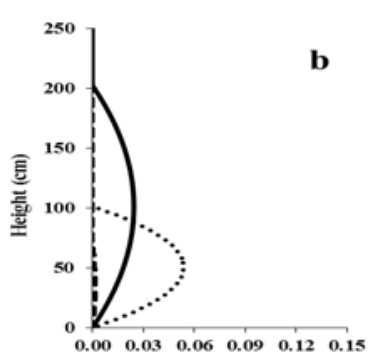

Lear Area Density
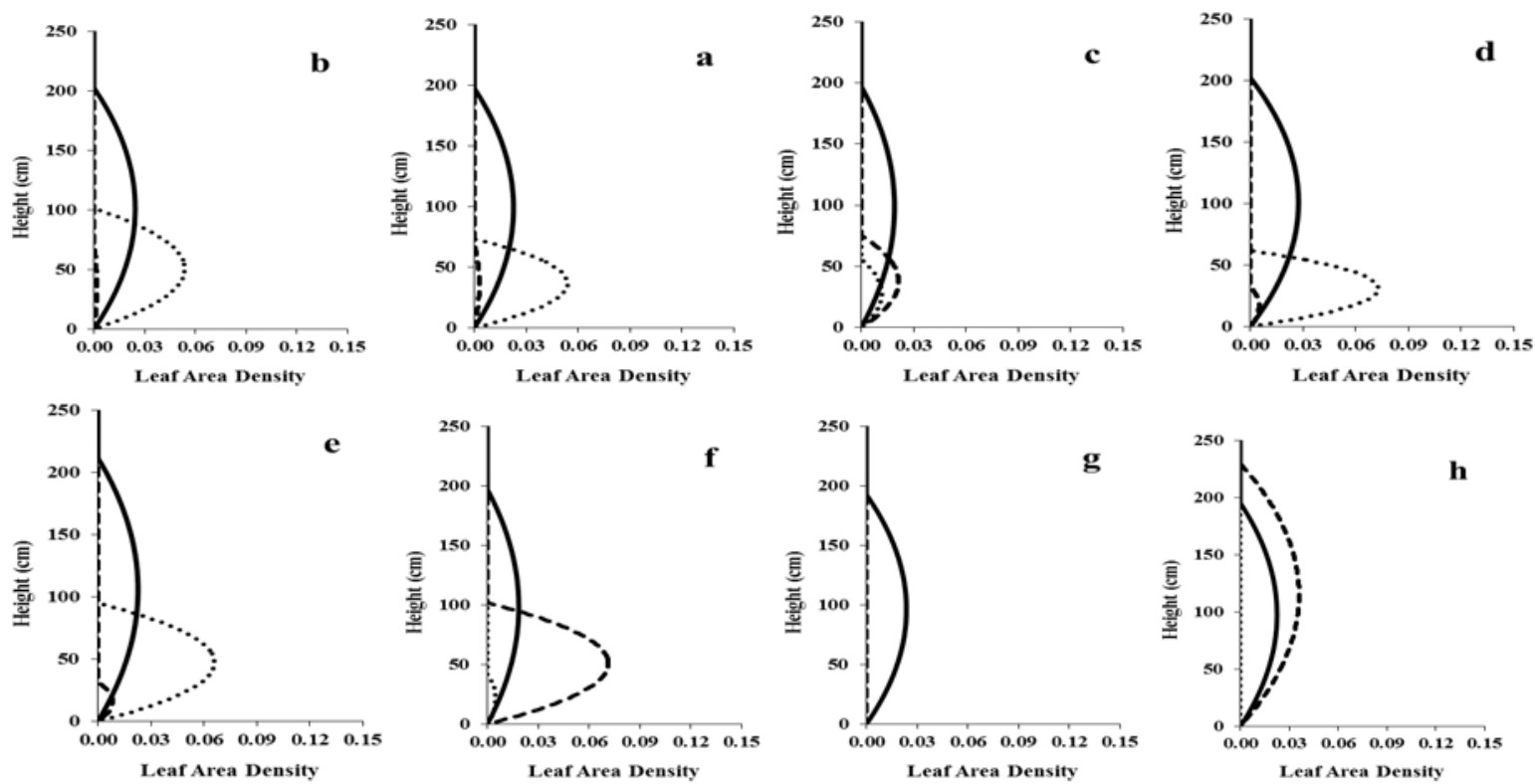

Figure 1: Leaf area density $\left(\mathrm{m}^{2} \mathrm{~m}^{-3}\right)$ of maize (-), cover crops (....), and velvetleaf (- - -) in the presence of bean (a, d), soybean (b, e), and berseem clover (c, f) same date planting with maize (a, b, c) and 21 days after planting of maize (d, e, f). Sole cropping of maize under weed control (g) and weed infestation (h).

The LAD of bean was higher than velvetleaf LAD at both planting dates (Figures 1a, 1d). The $\mathrm{LAD}_{\max }$ of soybean was positioned at higher canopy layer than those of the other cover crops at both planting dates (Figures 1b, 1e). In cover crops treatments, maize $\mathrm{LAD}_{\max }$ was distributed at higher canopy layer than that of velvetleaf (Figure 1). The $\mathrm{LAD}_{\max }$ of maize was recorded at higher layer of canopy $(106 \mathrm{~cm})$ in treatments with soybean planted 21 days after maize (Figure 1). LAD of 
velvetleaf was higher in sole cropping of maize under weedy condition (Figure $1 \mathrm{~h}$ ). $\mathrm{LAD}_{\max }$ of velvetleaf was observed at the height of $115 \mathrm{~cm}$, whereas maize $\mathrm{LAD}_{\max }$ was recorded at the height of $98 \mathrm{~cm}$ (Figure $1 \mathrm{~h}$ ). The $\mathrm{LAD}_{\max }$ of maize was observed at the height of $96 \mathrm{~cm}$ in weed-free treatments (Figure 1g).

\subsection{Absorbed light density}

Maize light interception decreased by velvetleaf interference under weedy conditions (Figure $2 \mathrm{~h}$ ). In this treatment, the maximum intercepted light by maize was recorded at upper canopy layers. Uchino et al. (2009) reported that intercepted light by main crop canopy reduced because most of the solar radiation was absorbed by upper canopy layers of weeds with high plant height. In addition, weed density and biomass decreased by reduction in available light (Bilalis et al., 2009). In the presence of bean and soybean, intercepted light by velvetleaf reduced significantly. Uchino et al. (2012) noted that light competition of main and cover crops with weeds affected the weed growth. The high leaf area index of maize, bean and soybean enhanced the ability of intercepting solar radiation by these plants and therefore decreased the absorbed light by velvetleaf (Poggio, 2005).
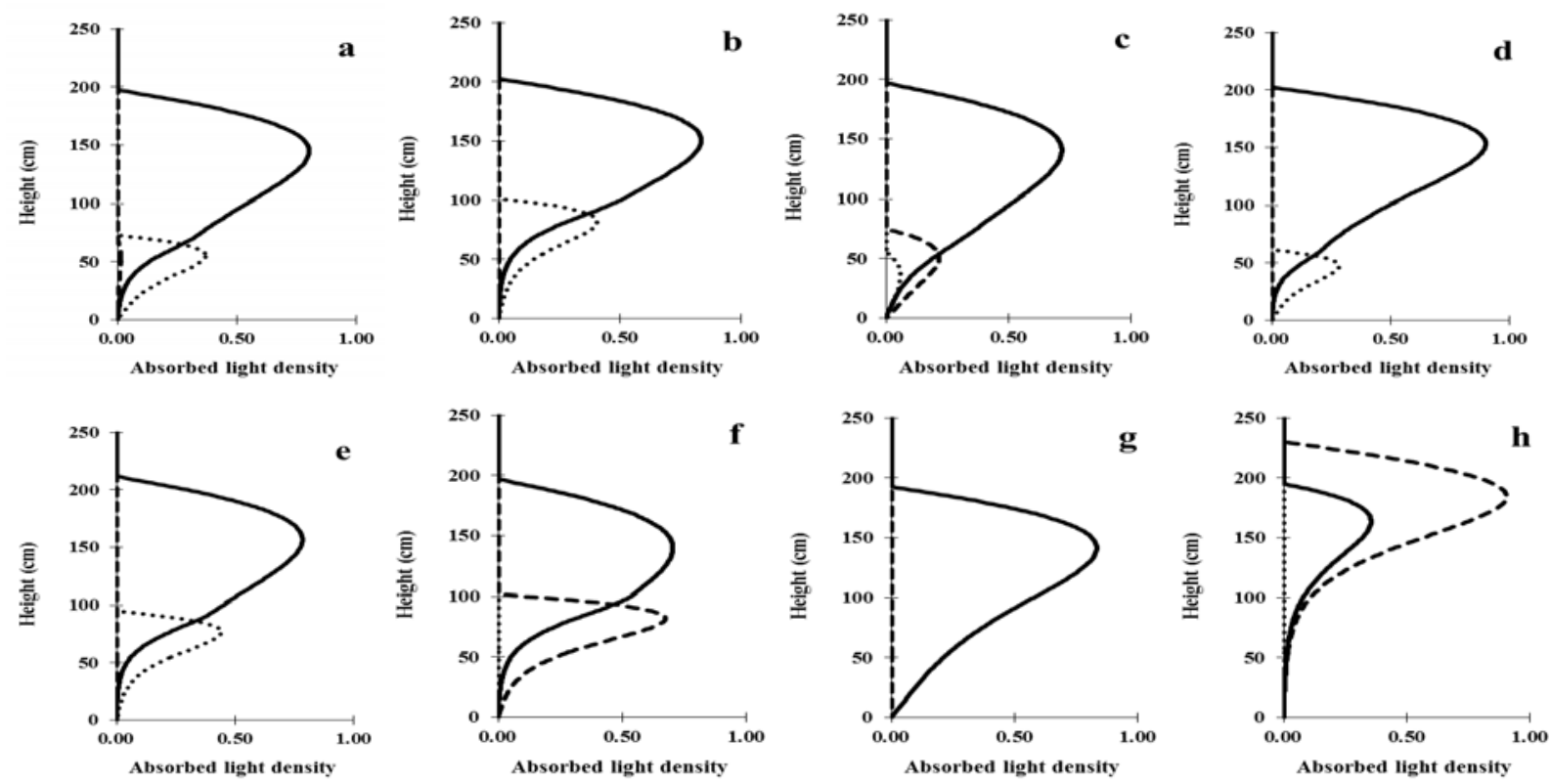

Figure 2: Absorbed light density percentage of maize (-), cover crops (....), and velvetleaf (- - -) in the presence of bean (a, d), soybean (b, e), and berseem clover (c, f) same date planting with maize (a, b, c) and 21 days after planting of maize $(\mathrm{d}, \mathrm{e}, \mathrm{f})$. Sole cropping of maize under weed control $(\mathrm{g})$ and weed infestation $(\mathrm{h})$.

Soybean decreased the absorbed light by lower layers of maize (Figures 2b, 2e). It was because of the greater height for soybean comparing to the other studied cover crops (Table 2). In contrast to soybean, most of the light intercepted at lower layers of maize canopy in treatments where bean was planted as a cover crop. (Figures 2a, 2b, 2d, 2e). Compared to the presence of another two cover crops, lower canopy layers of maize absorbed more light in the presence of clover due to poor light interception by clover (Figures 2c, 2f).

\subsection{Cumulative absorbed light}

The highest cumulative light interception by maize was observed in maize sole cropping under weedfree condition (Figure 3g). Velvetleaf reduced maize cumulative absorbed light, so cumulative absorbed light by maize dropped to below $50 \%$ (Figure 3h). Mondani et al. (2011) stated that weed competition decreased light interception of potato due to reduction in LAI and lodging of potato canopy. Bean and soybean decreased the cumulative absorbed light by velvetleaf, therefore light interception by maize increased compared to 
pure stand of maize under weedy conditions (Figures 3a, 3b, 3d, 3e, 3h). The reduction in light interception by velvetleaf in the presence of cover crops was generally due to the wider canopy architecture of broadleaf crops (such as bean and soybean) than the cereal crops (Borger et al., 2010).The bigger height and LAI of bean and soybean compared to clover also could be another reason for the reduction in light interception by velvetleaf (Table 2). In addition, when two or more plants existed in the same area, the competition for environmental resources among plants is inevitable (Zimdahl, 2004). Therefore, cover crops suppressed the velvetleaf growth through reduction in space for velvetleaf and enhancing intercompetition (Workayehu et al., 2011). Angiras and Sharma (1996) stated that reduction of row spacing between wheat plants increased the intercepted light by crops and reduced weed biomass. The cumulative absorbed light of velvetleaf was higher in clover treatments than other cover crops (Figures 3c, 3f). Bilalis et al. (2009) showed a significant reduction in available light for weeds caused by the vetch (Vicia sativa L.) rather than red clover (Trifolium pratense L.).
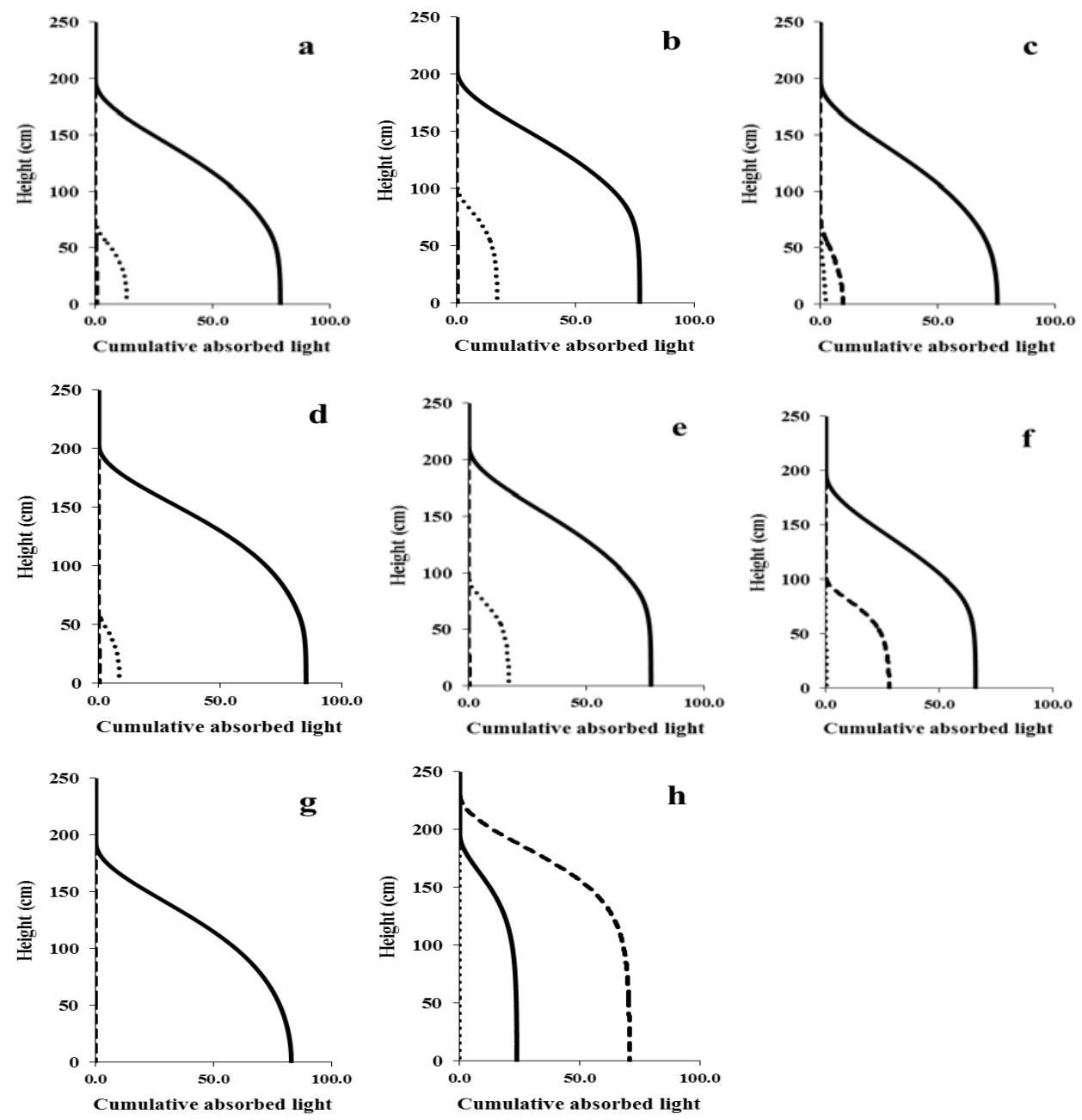

Figure 3. Cumulative absorbed light percentage of maize (-), cover crops (....), and velvetleaf (- - -) in the presence of bean (a, d), soybean (b, e), and berseem clover (c, f) same date planting with maize (a, b, c) and 21 days after planting of maize $(\mathrm{d}, \mathrm{e}, \mathrm{f})$. Sole cropping of maize under weed control $(\mathrm{g})$ and weed infestation $(\mathrm{h})$. 


\subsection{Yield of maize}

The highest yield of maize $\left(10,741 \mathrm{~kg} \mathrm{ha}^{-1}\right)$ was recorded in the sole cropping of maize under weed control (Figure 4). Olorunmaiye (2010) stated that maize grain yield under the various cover crops was similar, but cassava (Manihote sculentus Crantz) tuber yield was significantly higher in Mucuna pruriens 'Preta' than other cover crops and no cover crop treatment. The maize yield was higher when cover crops were planted 21 days after maize sowing. Bean, soybean and clover that planted 21 days after maize increased maize yield by $24.07 \%, 39.66 \%$, and $14.75 \%$, respectively, compared to pure stand of maize under weedy condition (Figure 4). In cover crop treatments, the highest yield of maize was observed in soybean cover crop treatments (Fig. 4). The highest yield of soybean and maize was observed in treatment sowing of cover crops planted 21 days after sowing main crops (Uchino et al., 2009). Abdin et al. (2000) also cited that maize grain yield in interseeded cover crop treatments was higher than maize pure stand under weedy conditions. Moreover, Ngouajio et al. (2003) reported that the highest yield of lettuce was obtained when summer cowpea was planted as a cover crop.

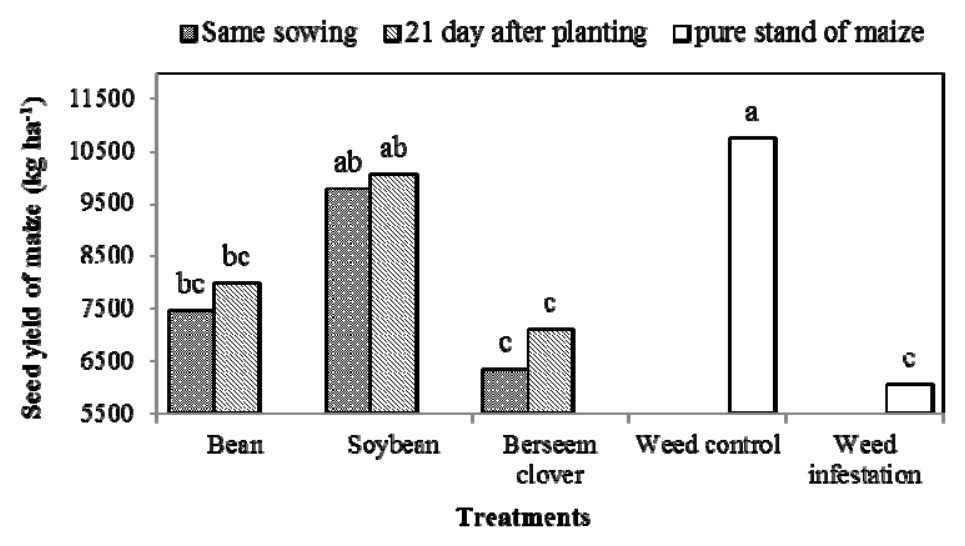

Figure 4. Effect of treatments on seed yield of maize. Columns with the same letter are not significantly different at the $5 \%$ level of probability.

Maize yield was the lowest in clover cover crop treatment. This yield reduction is probably result of clover's weak suppression effect on velvetleaf performance, in fact, clover presence also decreased the leaf area index of maize (Table 1) and increased the leaf area density of velvetleaf compared to bean and soybean (Figures 1c, 1f). One of the most important aims of crop management, especially in the presence of weeds, is the better capture of solar radiation by crops (Mondani et al., 2011). In general, soybean improved the yield of maize through increasing in the light interception by maize and reduction of light interception by velvetleaf compared to maize sole cropping under weed infestation (Figure 2).

\section{CONCLUSIONS}

The experimental data showed that bean and soybean as cover crops efficiently suppressed velvetleaf through reduction in velvetleaf leaf area index, plant height and leaf area density. Clover used as a cover crop was less effective in velvetleaf suppression probably due to the lower value of clover plant height, dry matter and LAI. An evaluation of maize yield and dry matter suggested that soybean successfully reduced velvetleaf growth and absorbed light. Therefore, utilizing soybean as a cover crop could be recommended as a method for weed control program in maize. This study provided more insight into the efficiency of three Fabaceae cover crops in weed suppression ability. 


\section{REFERENCES}

Abdin, O.A., Zhou X.M., Cloutier, D., Coulman, D.C., Faris, M.A., Smith, D.L., 2000. Cover crops and interrow tillage for weed control in short season maize (Zea mays). European Journal of Agronomy, 12: 93102. Doi: 10.1016/S1161-0301(99)00049-0

Akobundu, L.O., 1980. Live mulch: a new approach to weed control and crop production in the tropics. In: Proceedings 1980 Brit. Crop Protection Conference Weeds, 377-382. Brighton: British Crop Protection Council.

Angiras, N., Sharma, V., 1996. Influence of row orientation, row spacing and weed-control methods on physiological performance of irrigated wheat (Triticum aestivum L.). Indian Journal of Agronomy, 41: 41-47.

Arkebauer, T.J., Walter-Shea, E.A., Mesarch, M.A., Suykerand, A.E., Verma, S.B., 2009. Scaling up of $\mathrm{CO}_{2}$ fluxes from leaf to canopy in maize-based agroecosystems. Agriculture and Forest Meteorology, 149: 2110-2119. 10.1016/j.agrformet.2009.04.013

Barker, D.C., Knezevic, S.Z., Martin, A.R., Lindquis, J.L., 2006. Effect of nitrogen addition on the comparative productivity of corn and velvetleaf (Abutilon theophrasti). Weed Science, 54: 354-363.

BergaminFilho, A., Carneiro, S.M.T.P.G., Godoy, C.V., Amorim, L., Beger, R.D., Hau, B., 1997. Angular leaf spot of phaseolus beans: Relationships between disease, healthy leaf area, and yield. Phytopathology, 87(5): 506-515. Doi: 10.1094/PHYTO.1997.87.5.506

Bilalis, D., Karkanis, A., Efthimiadou, A., 2009. Effects of two legume crops, for organic green manure, on weed flora, under Mediterranean conditions: competitive ability of five winter season weed species. African Journal of Agricultural Research, 4(12): 1431-1441.

Borger, C.P.D., Hashem, A., Pathan, S., 2010. Manipulating crop row orientation to suppress weeds and increase crop yield. Weed Science, 58: 174-178. Doi: 10.1614/WS-09-094.1

Campiglia, E., Paolini, R., Colla, G., Mancinelli, R., 2009. The effects of cover cropping on yield and weed control of potato in a transitional system. Field Crop Research, 112: 16-23. Doi: 10.1016/j.fcr.2009.01.010

Campiglia, E., Mancinelli, R., Radicetti, E., Caporali, F., 2010. Effect of cover crops and mulches on weed control and nitrogen fertilization in tomato (Lycopersicom esculentum Mill.). Crop Protection, 29: 354-363. Doi: 10.1016/j.cropro.2009.12.001

Ciganda, V., Gitelson, A., Schepers, J., 2008. Vertical profile and temporal variation of chlorophyll in maize canopy: quantitative "crop vigor" indicator by means of reflectance-based techniques. Agronomy Journal, 100(5): 1409-1417. Doi: 10.2134/agronj2007.0322
Dermody, O., Longs, S.P., McConnaughay, K., DeLucia, E., 2008. How do elevated $\mathrm{CO}_{2}$ and $\mathrm{O}_{3}$ affect the interception and utilization of radiation by a soybean canopy? Global Change Biology, 14: 556-564. 10.1111/j.1365-2486.2007.01502.x

Flenet, F., Kiniry, J.R., Board, J.F., Westgate, M.E., Reicosky, D.C., 1996. Row spacing effects on light extinction coefficients of corn, sorghum, soybean, and sunflower. Agronomy Journal, 88: 185-190. Doi: 10.2134/agronj1996.00021962008800020011x

Haj Seyed Hadi, M.R. 2012. Effect of weed competition on radiation use efficiency of potato. International Journal of Agriculture and Crop Science, 4(9): 508511.

Hiltbrunner, J., Liedgens, M., Bloch, L., Stamp, P., Streit, B., 2007. Legume cover crops as living mulches for winter wheat: Components of biomass and the control of weeds. Europeann Journal of Agronomy, 26: 21-29. Doi: 10.1016/j.eja.2006.08.002

Hollander, N.G., Bastiaans, L., Kropff, M.J., 2007., Clover as a cover crop for weed suppression in an intercropping design, I. Characteristics of several clover species. Europeann Journal of Agronomy, 26: 92-103. 10.1016/j.eja.2006.08.011

Kropff. M.J., Vanlaar, HH.., Ten Berge, H.F.M., 1993. ORYZA1, A basic model for irrigated lowland rice production. Los Banos. International Rice Research Institute. p. 89.

Lindquist, J.L., 2001. Performance of INTERCOM for predicting corn-velvetleaf interference across northcentral United States. Weed Science, 49: 195-201. Doi: $10.1614 / 0043-$ 1745(2001)049[0195:POIFPC]2.0.CO;2

Lindquist, J.L., Mortensen, D.A., 1999. Ecophysiological characteristics of four maize hybrids and Abutilon theophrasti. Weed Research, 39(4): 271-285. Doi: 10.1046/j.1365-3180.1999.00143.x

Lindquist, J.L., Arkebauer, T.J., Walters, D.T., Cassman, K.G., Dobermann, A., 2005. Maize radiation use efficiency under optimal growth conditions. Agronomy Journal, 97: 72-78. Doi: 10.2134/agronj2005.0072

Liu, T., Song, F., Liu, S., Zhu, X. 2012. Light interception and radiation use efficiency response to narrow-wide row planting patterns in maize. Australian Journal of Crop Science, 6(3): 506-513.

Maddonni, G.A., Otegui, M.E., Cirilo, A.G., 2001. Plant population density, row spacing and hybrid effects on maize canopy architecture and light attenuation. Field Crops Research, 71: 183-193. Doi: 10.1016/S03784290(01)00158-7

Acta agriculturae Slovenica, 107 - 2, september 2016 
Mondani, F., Golzardi, F., Ahmadvand, G., Ghorbani, R., Moradi, R., 2011. Influence of weed competition on potato growth, production and radiation use efficiency. Notulae Botanicae Horti Agrobotanici Cluj-Nopoca. 3(3): 42-52.

NasiriMohallati, M., Kropff, M.J., 1997. Simulation model for crop-weed competition modified for LAD distribution function and extinction coefficient based on lead dispersion. Wageningen Agricultural University. The Netherland.

Ngouajio, M., McGiffen, M.E., Hutchinson, C.M., 2003. Effect of cover crop and management system on weed populations in lettuce. Crop Production, 22: 57-64. Doi: 10.1016/S0261-2194(02)00111-4

Olorunmaiye, P.M., 2010. Weed control potential of five legume cover crops in maize/cassava intercrop in a Southern Guinea savanna ecosystem of Nigeria. Australian Journal of Crop Science, 4(5): 324-329.

Poggio, S.L., 2005. Structure of weed communities occurring in monoculture and intercropping of field pea and barley. Agriculture, Ecosystem and Environment, 109: 48-58. Doi: 10.1016/j.agee.2005.02.019

Sassenrath-Cole, G.F., 1995. Dependence of canopy light distribution on leaf and canopy structure for two cotton (Gossypium) species. Agriculture and Forest Meteorology, 77: 55-72. Doi: 10.1016/01681923(95)02238-S

Shili-Touzi, I., Tourdonnet, S. De, Launay, M., Dore, T., 2010. Dose intercropping winter wheat (Triticum aestivum) with red fescue (Festuca rubra) as a cover crop improves agronomic and environmental performance: A modeling approach. Field Crop Research, 16: 218-229. Doi: 10.1016/j.fcr.2009.11.007

Soleymani, A., Shahrajabian, M.H., 2012. Influence of nitrogen fertilizer on ash, organic carbon, phosphorus, potassium, and fiber of forage corn intercropped by tree cultivars of berseem clover as cover crops in semi arid region of Iran. International Journal of Biology, 4(3): 38-43. Doi: 10.5539/ijb.v4n3p38

Steinmaus, S., Elmore, C.L., Smith, R.J., Donaldson D., Weber E.A., Roncoroni, J.A., 2008. Mulched cover crops as an alternative to conventional weed management systems in vineyards. Weed Research,
48(3): $\quad 273-281$.
Doi:
10.1111/j.1365-
3180.2008.00626.x

Tsubo, M., Walker, S., Ogindo, H.O., 2005. A simulation model of cereal-legume intercropping systems for semi-arid regions. Field Crops Research, 93: 10-22. 10.1016/j.fcr.2004.09.002

Uchino, H., Iwama, K., Jitsuyama, Y., Ichiyama, K., Sugiura, E., Yudate, T., 2012. Effect of interseeding cover crops and fertilization on weed suppression under an organic and rotational cropping system. 1. Stability of weed suppression over years and main crops of potato, maize and soybean. Field Crop Research, 127: 9-16. Doi: 10.1016/j.fcr.2011.10.007

Uchino, H., Iwama, K., Jitsuyama, Y., Yudate, T., Nakamura, S., 2009. Yield losses of soybean and maize by competition with interseeded cover crops and weeds in organic-based cropping systems. Field Crop Research, 113: 342-351. Doi: 10.1016/j.fcr.2009.06.013

Udensi. E.U., Akobundu, I.O., Ayeni, A.O., Chikoye, D., 1999 Management of cogongrass (Imperata cylindrica) using velvet bean (Mucuna prunens var. utilis) and herbicides. Weed Technology, 13: 201-208.

Unay, A., Tan, E., Konak, C., Celen, E., 2005. Influences of winter cover crop residues and tillage on cotton lint yield and quality. Pakistan Journal of Botany, 37(4): 905-911.

Vazin, F., Madani, A., Hassanzadeh, M., 2010. Modeling light interception and distribution in mixed canopy of redroot pigweed (Amaranthus retroflexus) in competition with corn (Zea mays). Notulae Botanicae Horti Agrobotanici Cluj-Nopoca, 38(3): 128-134.

Wang, D., Shannon, M.C., Grieve, C.M., 2001. Salinity reduces radiation absorption and use efficiency in soybean. Field Crop Research, 69: 267-277. Doi: 10.1016/S0378-4290(00)00154-4

Workayehu, T., Mazengia, W., Hidoto, L., 2011. Growth habit, plant density and weed control on weed and root yield of sweet potato (Ipomoea batatas L.) Areka, Southern Ethiopia. Journal of Horticulture and Forestry, 3(38): 251-258.

Zimdahl, R.L., 2004. Weed-Crop Competition-A Review, second edition. Blackwell Publishing, IOWA, USA. 